\title{
TICK-BORNE ENCEPHALITIS - A REVIEW OF CURRENT EPIDEMIOLOGY, CLINICAL SYMPTOMS, MANAGEMENT, AND PREVENTION
}

\section{KLESZCZOWE ZAPALENIE MÓZGU - PRZEGLĄD AKTUALNEJ EPIDEMIOLOGII, OBJAWÓW KLINICZNYCH, POSTĘPOWANIA I PROFILAKTYKI}

\author{
Medical University of Bialystok, Department of Pediatric Infectious Diseases \\ Uniwersytet Medyczny w Białymstoku, Klinika Obserwacyjno-Zakaźna Dzieci
}

\begin{abstract}
Tick-borne encephalitis virus (TBEV), which causes central nervous system infections, is a major health problem in Europe and Asia. This virus is transmitted mainly via the bite of a tick. However, an infection may also occur as a result of consuming raw milk. In 2018, a total of 3092 cases of tick-borne encephalitis (TBE) were reported in EU countries. In recent years, TBE has emerged in previously unaffected regions; thus, new endemic areas have been identified. Most cases of TBE occur in spring and autumn, which correlates with increased tick activity. TBE is found in all age groups, including infants. The clinical presentation of TBE varies, but the severity of the infection and risk of complications increase with age. Post-encephalitic syndrome, which affects up to $50 \%$ of infected individuals, significantly reduces quality of life. Currently, there is no effective treatment for TBE, and supportive management is used in the acute phase of the disease. Therefore, anti-TBE immunization and the avoidance of tick bites are of key importance in preventing this infection.
\end{abstract}

Key words: tick-borne encephalitis virus, tick-borne encephalitis, TBE, ticks

\section{STRESZCZENIE}

CEL. Wirus kleszczowego zapalenia mózgu (KZM), powodujący zakażenia ośrodkowego układu nerwowego, jest istotnym problemem zdrowotnym w Europie i Azji. Wirus ten przenoszony jest głównie w następstwie wkłucia się kleszcza, chociaż zakażenie może być również skutkiem spożycia niepasteryzowanego mleka. W 2018 roku zgłoszono w krajach UE łącznie 3092 przypadki zachorowań. W ostatnich latach obserwuje się rozszerzanie zasięgu występowania KZM oraz powstawania nowych terenów endemicznych wirusa. Większość przypadków zakażenia występuje w okresie wiosennym i jesiennym, co koreluje z najwyższą aktywnością kleszczy w tych porach roku. KZM stwierdzane jest w każdej grupie wiekowej, w tym u najmłodszych dzieci. Obraz kliniczny zakażenia jest zróżnicowany, ale ryzyko ciężkości przebiegu i trwałych powikłań po przechorowaniu KZM wzrasta wraz z wiekiem. Występujący u nawet 50\% pacjentów zespół postencefalityczny istotnie obniża jakość życia chorych. Obecnie nie ma skutecznej metody leczenia KZM, a postępowanie w ostrym okresie choroby ma charakter wyłącznie objawowy. $Z$ tego powodu kluczowe znaczenie w prewencji zakażenia mają szczepienia przeciwko KZM oraz działania profilaktyczne minimalizujące możliwość ukłucia przez kleszcza.

Słowa kluczowe: wirus kleszczowego zapalenia mózgu, kleszczowe zapalenie mózgu, KZM, kleszcze 


\section{INTRODUCTION}

Tick-borne encephalitis (TBE) is a viral disease of the central nervous system caused by the RNA virus of the Flaviviridae family in the genus Flavivirus. This genus also includes West Nile fever virus, Dengue fever, yellow fever virus, Japanese encephalitis virus, and Zika virus. There are three main subtypes of tick-borne encephalitis virus (TBEV): Far Eastern, Siberian, and European. However, RNA viruses constantly mutate. Based on an analysis of the phylogenetic evolution of TBEV, two new subtypes were recently proposed: the Himalayan type, isolated in the Tibetan Plateau, and the Baikalian type, from the areas of Lake Baikal (1). TBE is endemic in Europe and Asia, ranging from eastern France to northern Japan (2-4). The occurrence of ticks and tick-borne diseases is constantly expanding to new areas. Over the past decades, an increasing number of reported cases has been observed $(5,6)$. Vaccination against TBE among at-risk groups in Poland has been recommended since 1993, which led to a statistically significant decrease in the hospitalization of foresters and forest workers. At present, the majority of infections occur in people not professionally connected with forestry and tourists traveling to endemic areas, including children (7).

\section{ETIOLOGY AND DIAGNOSTIC METHODS}

In Europe, the primary viral vectors are ticks. The most important among them are the species Ixodes ricinus in Europe and Ixodes persulcatus, the latter of which occurs mainly in Russia. In Poland, 21 tick species have been described, among which two species are of the greatest importance: the common tick, Ixodes ricinus, and the meadow tick, Dermacentor reticulatus (8). Each development stage of this arachnid, from larva, to nymph, to adult, can be a vector of infection, and each needs a vertebrate's blood to develop. The entire tick development cycle lasts $2-4$ years (9).

Human infections occur mainly through tick bites. The virus present in the saliva of the arthropod is transmitted to the skin, where it then penetrates the lymph nodes followed by the central nervous system (CNS). Infection is also possible as a result of raw milk consumption (10). The majority of infections with TBEV are asymptomatic (11). The symptomatic course of the disease includes mild aseptic meningitis, encephalitis, and myelitis (12). When the infection spreads to the $\mathrm{CNS}$, the virus is usually no longer present in the blood or cerebrospinal fluid, which limits the use of molecular methods for TBE diagnosis. Although RT-PCR is a sensitive and specific method that allows the rapid diagnosis of flaviviral infections in humans, its effectiveness is only high in the acute phase of infection due

\section{WSTĘP}

Kleszczowe zapalenie mózgu (KZM) jest wirusową chorobą ośrodkowego układu nerwowego wywołaną przez wirusa RNA z rodziny Flaviviridae, rodzaju Flavivirus. Rodzaj ten obejmuje również m. in. wirusa gorączki Zachodniego Nilu, Dengi, żółtej gorączki, japońskiego zapalenia mózgu oraz wirusa Zika. Wyróżnia się trzy główne typy wirusa KZM: dalekowschodni, syberyjski oraz europejski. Wirusy te stale mutują. Na podstawie analizy ich ewolucji filogenetycznej zaproponowano wyodrębnienie nowych typów: typu himalajskiego z obszaru Wyżyny Tybetańskiej oraz typu bajkalskiego z obszarów jeziora Bajkał (1). KZM występuje endemicznie w wielu regionach Europy i Azji, sięgając od wschodnich terenów Francji po północną Japonię (2-4). Zasięg występowania kleszczy i przenoszonych przez nie chorób stale rozszerza się o nowe obszary. Na przestrzeni ostatnich dekad zaobserwowano rosnącą liczbę zgłaszanych przypadków KZM $(5,6)$. Od 1993 roku w Polsce zaleca się szczepienie przeciwko KZM w grupach ryzyka, co pozwoliło na zdecydowane ograniczenie hospitalizacji w grupie leśników i pracowników leśnych. Obecnie większość zakażeń dotyczy osób zawodowo niezwiązanych z leśnictwem, turystów podróżujących do terenów endemicznych, a także dzieci (7).

\section{ETIOLOGIA I METODY DIAGNOSTYCZNE}

W Europie głównym wektorem wirusa są kleszcze. Dominującą rolę odgrywają gatunki takie jak Ixodes ricinus $\mathrm{w}$ Europie oraz Ixodes persulcatus występujący głównie w Rosji. W Polsce opisano 21 gatunków kleszczy, spośród których największe znaczenie mają dwa gatunki: kleszcz pospolity Ixodes ricinus i kleszcz łąkowy Dermacentor reticulatus (8). Każde stadium rozwojowe pajęczaka, począwszy od larwy, poprzez nimfę, aż do postaci dorosłej, może być wektorem infekcji oraz każde potrzebuje krwi kręgowca do rozwoju. Cały cykl rozwojowy kleszczy trwa 2-4 lata (9).

Do zakażenia człowieka dochodzi głównie wskutek wkłucia się kleszcza. Wirus obecny w ślinie stawonoga trafia do skóry, skąd drogami limfatycznymi przenika do węzłów chłonnych i dalej do ośrodkowego układu nerwowego (OUN). Możliwe jest też zakażenie $\mathrm{w}$ wyniku spożywania niepasteryzowanego mleka (10). Większość zakażeń wirusem KZM przebiega bezobjawowo (11). Przebieg objawowy obejmuje łagodne aseptyczne zapalenie opon, zapalenie mózgu i zapalenie rdzenia (12). W fazie zajęcia OUN wirus przeważnie nie jest już obecny we krwi, ani w płynie mózgowo-rdzeniowym, co ogranicza zastosowanie metod molekularnych w diagnostyce KZM. Pomi- 
to the short duration of viremia or low viremia in the blood of infected patients (13). Therefore, the detection of specific antibodies is the basis for TBE diagnosis (14). When interpreting the results of serological tests, it should be taken into account that infections caused by Flaviviridae viruses induce the production of cross-reactive antibodies. This results in difficulties in the unequivocal interpretation of the obtained results. In addition, a past flavivirus infection significantly hinders diagnosis, which is of particular importance in regions where there are many antigenically associated flaviviruses (15). One of the major advances in the diagnosis of these infections was the development of multiplex tests that allow the simultaneous detection of antibodies directed against several flaviviruses. For this purpose, high-density microarrays containing peptides from various flaviviruses were developed. Microsphere-based immunoassays for measuring IgM and $\operatorname{IgG}$ directed against many types of flaviviruses are currently the method of choice for the diagnosis of TBE $(15,16)$.

\section{EPIDEMIOLOGY}

TBE is a seasonal disease caused by the arachnid's activity in the months of April-October. The incidence of TBE peaks in spring (June and July) and autumn (September and October). In recent years, a worrying increase in the number of reported cases has been noted. In 2018, compared to the previous year, the number of reported cases of TBE doubled in Slovakia, Lithuania and Croatia and increased by approximately $20 \%$ in Germany (2). In 2016 in Netherlands the emergence of this disease was observed for the first time, while in French Alsace there was a threefold increase in the number of TBE infections $(17,18)$. This observed increase is caused by multiple factors, including the growing awareness and detectability of infections, the spread of ticks to new areas, and an increase in the population of ticks. Observable climate changes - particularly milder winters and warmer summers-also facilitate tick survival (19).

TBE is endemic in Central and Eastern Europe, southern Russia, and in Scandinavia. In the European Union (EU), there are between 2000 to 4000 reported cases annually, $95 \%$ of which require hospitalization, and every hundredth patient dies (19). In 2018, a total of 3,092 cases were reported in EU countries, and 16 people died $(0.6 \%)$. The number of countries reporting cases increased from 19 in 2012 to 26 in 2018. In 2018, the majority of cases occurred in the Czech Republic, Germany, Sweden, and Lithuania (Table 1) (2). Importantly, in the same year, $35.4 \%$ of all reported cases occurred in the Czech Republic and Lithuania, despite the fact that their total population represented mo że RT-PCR jest czułą i specyficzną metoda, która pozwala na szybką diagnozę infekcji flawiwirusowej u ludzi, jej skuteczność jest wysoka jedynie w ostrej fazie infekcji, na co ma wpływ krótki czas utrzymywania się wiremii lub niski poziom wiremii we krwi zakażonych pacjentów (13). Dlatego podstawą rozpoznania KZM jest wykrycie swoistych przeciwciał (14). Interpretując wyniki badań serologicznych należy wziąć pod uwagę fakt, że infekcje spowodowane wirusami z rodziny Flaviviridae indukują wytwarzanie przeciwciał reagujących krzyżowo. Skutkuje to trudnościami w jednoznacznej interpretacji uzyskanych wyników, a przebyte $\mathrm{w}$ przeszłości zakażenie flawiwirusami znacznie utrudnia tę diagnostykę, co ma szczególne znaczenie w rejonach, w których występuje wiele flawiwirusów powiązanych antygenowo (15). Jednym z głównych postępów w dziedzinie diagnozowania tych zakażeń było opracowanie testów multipleksowych, które pozwalają na jednoczesne wykrycie przeciwciał skierowanych przeciwko kilku flawiwirusom. W tym celu opracowano mikromacierze o dużej gęstości zawierające peptydy pochodzące $z$ różnych flawiwirusów. Oparte na mikrosferach testy immunologiczne do pomiaru IgM i IgG skierowane przeciwko wielu rodzajom flawiwirusów sa obecnie metoda $z$ wyboru $w$ diagnostyce $(15,16) \mathrm{w}$ rejonach, gdzie istnieje ryzyko współzakażenia różnymi flawiwirusami.

\section{EPIDEMIOLOGIA}

KZM jest chorobą sezonową ze względu na aktywność pajęczaka w miesiącach kwiecień - październik. Zakażenia u ludzi charakteryzują się dwoma szczytami zachorowań: w okresie wiosennym (czerwiec, lipiec) i jesiennym (wrzesień, październik). Na przestrzeni ostatnich lat zauważono niepokojący wzrost liczby raportowanych przypadków. W 2018 roku, w porównaniu do roku poprzedniego, liczba zgłoszonych przypadków KZM podwoiła się na Słowacji, Litwie i Chorwacji, a w Niemczech wzrosła o blisko 20\% (2). W Holandii w 2016 roku zaobserwowano pojawienie się tej choroby po raz pierwszy, podczas gdy na terenie Francji w rejonie Alzacji zanotowano aż trzykrotny wzrost liczby zakażenia KZM $(17,18)$. Przyczyną obserwowanego wzrostu jest przypuszczalnie wiele czynników. Może on wynikać częściowo z rosnącej świadomości i wykrywalności zakażeń, rozprzestrzeniania się kleszczy na nowe obszary, a także zwiększenia się populacji kleszczy. Kierunek obserwowanych zmian klimatycznych, lagodniejsze zimy oraz cieplejsze lato ułatwiają kleszczom przeżycie (19).

Choroba występuje endemicznie w Europie Środkowej i Wschodniej, w południowej części Rosji oraz w Skandynawii. Rocznie w Unii Europejskiej (UE) 
Table I. Number of cases and incidence per 100,000 inhabitants in selected EU countries. ${ }^{a}$

Tabela I. Liczba zachorowań oraz zapadalność/100 tys. mieszkańców w wybranych krajach EU. ${ }^{a}$

\begin{tabular}{|c|c|c|c|c|c|c|c|c|c|c|}
\hline \multirow[b]{2}{*}{$\begin{array}{l}\text { Country / } \\
\text { Kraj }\end{array}$} & \multicolumn{2}{|c|}{2014} & \multicolumn{2}{|c|}{2015} & \multicolumn{2}{|c|}{2016} & \multicolumn{2}{|c|}{2017} & \multicolumn{2}{|c|}{2018} \\
\hline & 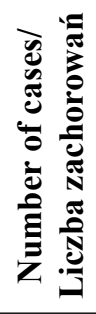 & 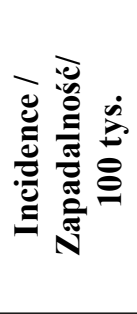 & 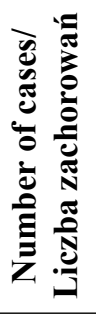 & 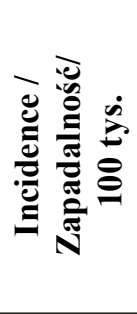 & 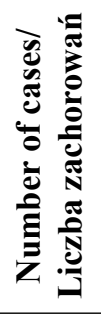 & 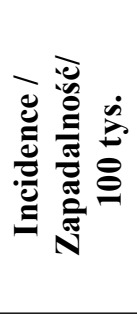 & 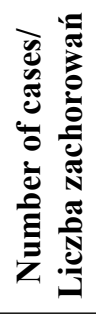 & 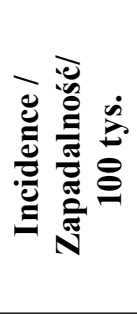 & 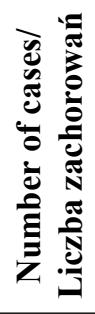 & 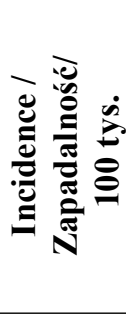 \\
\hline $\begin{array}{l}\text { Austria/ } \\
\text { Austria }\end{array}$ & 81 & 1.0 & 79 & 0.9 & 95 & 1.1 & 123 & 1.4 & 170 & 1.9 \\
\hline $\begin{array}{l}\text { Croatia } \\
\text { Chorwacja/ }\end{array}$ & 23 & 0.5 & 26 & 0.6 & 6 & 0.1 & 10 & 0.2 & 24 & 0.5 \\
\hline $\begin{array}{l}\text { Czech } \\
\text { Republic/ } \\
\text { Czechy }\end{array}$ & 410 & 3.9 & 349 & 3.3 & 565 & 5.4 & 677 & 6.4 & 713 & 6.7 \\
\hline $\begin{array}{l}\text { Estonia/ } \\
\text { Estonia }\end{array}$ & 82 & 6.2 & 115 & 8.7 & 80 & 6.1 & 84 & 6.4 & 85 & 6.4 \\
\hline $\begin{array}{l}\text { Finland/ } \\
\text { Finlandia }\end{array}$ & 47 & 0.9 & 68 & 1.2 & 61 & 1.1 & 82 & 1.5 & 79 & 1.4 \\
\hline $\begin{array}{l}\text { Lithuania/ } \\
\text { Litwa }\end{array}$ & 149 & 7.4 & 141 & 7.1 & 91 & 4.6 & 178 & 9.1 & 384 & 13.7 \\
\hline $\begin{array}{l}\text { Latvia/ } \\
\text { Lotwa }\end{array}$ & 353 & 12.0 & 336 & 11.5 & 633 & 21.9 & 474 & 16.6 & 139 & 5.2 \\
\hline $\begin{array}{l}\text { Germany/ } \\
\text { Niemcy }\end{array}$ & 264 & 0.3 & 220 & 0.3 & 347 & 0.4 & 485 & 0.6 & 583 & 0.7 \\
\hline $\begin{array}{l}\text { Norway/ } \\
\text { Norwegia }\end{array}$ & 13 & 0.3 & 9 & 0.2 & 12 & 0.2 & 16 & 0.3 & 26 & 0.5 \\
\hline $\begin{array}{l}\text { Poland/ } \\
\text { Polska }\end{array}$ & 131 & 0.3 & 115 & 0.3 & 211 & 0.6 & 196 & 0.5 & 197 & 0.4 \\
\hline $\begin{array}{l}\text { Slovakia/ } \\
\text { Slowacja }\end{array}$ & 115 & 2.1 & 80 & 1.5 & 169 & 3.1 & 75 & 1.4 & 156 & 2.9 \\
\hline $\begin{array}{l}\text { Slovenia/ } \\
\text { Slowenia }\end{array}$ & 100 & 4.9 & 62 & 3.0 & 83 & 4.0 & 102 & 4.9 & 153 & 7.4 \\
\hline $\begin{array}{l}\text { Sweden/ } \\
\text { Szwecja }\end{array}$ & 178 & 1.8 & 268 & 2.7 & 238 & 2.4 & 365 & 3.7 & 385 & 3.5 \\
\hline $\begin{array}{l}\text { Hungary/ } \\
\text { Węgry }\end{array}$ & 26 & 0.3 & 22 & 0.2 & 14 & 0.1 & 14 & 0.1 & 32 & 0.3 \\
\hline
\end{tabular}

${ }^{a}$ Adapted from European Centre for Disease Prevention and Control. Tick-borne encephalitis. In: Annual epidemiological report for 2018. Stockholm: ECDC; 2019

${ }^{\mathrm{a}}$ Źródło: European Centre for Disease Prevention and Control. Tick-borne encephalitis. W: Annual epidemiological report for 2018. Stockholm: ECDC; 2019

only $2.7 \%$ of the population of the countries covered by this analysis.

According to data published in 2019 by the European Centre for Disease Prevention and Control (ECDC), the majority of TBE cases occur in people between 45 and 64 years of age (1 120 cases, 0.8 per 100,000 people). In all age groups, approximately $60.6 \%$ of cases occurred in males, and the ratio of males to females was 1.5:1. The lowest incidence was recorded in children under 4 years of age $(0.2$ out of 100,000$)$ (2). Notably, TBEV infections occur in all age groups, notuje się od około 2000 do 4000 przypadków, z czego $95 \%$ zarejestrowanych przypadków wymaga hospitalizacji, a co setny pacjent umiera (19). W 2018 roku zgłoszono w krajach UE łącznie 3092 przypadków zachorowań, 16 osób zmarło $(0,6 \%)$. Liczba krajów raportujących przypadki zachorowań wzrosła z 19 w 2012 r. do 26 w 2018 r. W 2018 roku najwięcej przypadków wystąpiło na terenie Czech, Niemiec, Szwecji oraz Litwy (Tab. I) (2). Co istotne, w tym samym roku aż 35,4\% wszystkich zgłoszonych przypadków wystąpiło w Czechach i na Litwie, pomimo że łączna liczba 
including infants (20). The difference in the frequency of TBE in different age groups is not due to different susceptibility levels to the infection but likely due to the effect of each group's preferred everyday activities, types of rest, and working conditions, which all determine one's exposure to tick bites (19).

The number of TBE infections has been registered in Poland since 1970. In the years 2000-2015, a total of 3,662 cases of TBE $(0.33-0.92 / 100,000$ inhabitants) were recorded in Poland (10). The highest number of cases, nearly 50\%, was reported in Podlaskie (6.17/100,000 people) and the Warmian-Masurian voivodeships (1.75/100,000 people). Currently, according to the reports of regional sanitary-epidemiological stations, on average, 200-300 cases of TBE are registered in Poland annually. In 2019, the incidence rate of TBE for Poland was 0.69/100,000 inhabitants (21). According to environmental investigations and serological surveys, TBE presumably occurs all over Poland $(22,23)$. Compared to north-eastern Poland, more CNS inflammations of an undetermined etiology are recorded in the voivodeships located in the south-western and south-eastern parts of the country (24). It can, therefore, be assumed that some of the undefined neuroinfections are, in fact, undiagnosed TBE cases. This is especially probable because the incidence of TBE is statistically significantly higher in the immediate vicinity of the southern regions of Poland, the Czech Republic, and Slovakia (about 6.4/100,000). In addition, the reasons for underestimating the number of TBE cases may include an atypical course of the disease, limited access to diagnostics, and, unfortunately, neglecting to report cases of infection (25).

\section{TREATMENT}

The medical care of TBEV patients consists of symptomatic treatment. In milder cases, the administration of antipyretic, analgesic, antiemetic, and antiedema drugs, as well as the management of electrolytes (hyponatraemia) and acid-base imbalances, is required (26). There are no clearly defined treatment methods or guidelines. The lack of consensus regarding the duration of treatment and doses of drugs forces doctors to introduce their own approaches. According to our own experience, the use of dexamethasone in children with severe TBE at a dose of up to $0.6 \mathrm{mg} / \mathrm{kg} / \mathrm{day}$ (maximum $16 \mathrm{mg} /$ day) in four divided doses over 2-5 days tapered over 1-2 days produces beneficial therapeutic effects. Individual courses of treatment for patients with analgosedation, hyperventilation, hypothermia, decompressive hemicraniectomy, and intravenous immunoglobulins have also been described (27). Although antiviral therapies are currently not applicable in clinical practice, many in vitro studies offer the pos- ludności w tych krajach reprezentowała tylko 2,7\% populacji krajów objętych analizą.

Według danych opublikowanych w 2019 roku przez Europejskie Centrum ds. Zapobiegania i Kontroli Chorób (ECDC), zakażenie wirusem KZM najczęściej jest obserwowane u osób między 45 a 64 rokiem życia (1 120 przypadków; 0,8 na 100000 ludności). We wszystkich grupach wiekowych około $60,6 \%$ przypadków stanowili mężczyźni, a stosunek płci męskiej do żeńskiej wynosił 1,5:1. Najniższą zapadalność odnotowano wśród dzieci poniżej 4 roku życia $(0,2$ na 100 000) (2). Na uwagę zasługuje jednak fakt, że zakażenia wirusem KZM stwierdzane są w każdej grupie wiekowej, w tym u niemowląt (20). Zróżnicowanie częstości występowania zakażeń w różnych grupach wiekowych nie wynika $z$ odmiennej podatności na zakażenie. Jest to raczej efekt preferowanej aktywności, warunków pracy i wybieranej formy odpoczynku, które warunkują ekspozycję na atak kleszcza (19).

Liczba zakażeń KZM jest rejestrowana w Polsce od 1970 roku. W latach 2000-2015 w Polsce odnotowano łącznie 3662 zachorowania na KZM $(0,33-0,92 / 100$ 000 mieszkańców)(10). Największą liczbę zachorowań zgłoszono w województwie podlaskim $(6,17 / 100000$ osób) i warmińsko-mazurskim (1,75/100 000 osób), gdzie zanotowano około $50 \%$ wszystkich zachorowań w Polsce. Obecnie według raportów regionalnych stacji epidemiologicznych średnio w całej Polsce rejestruje się rocznie 200-300 przypadków KZM. W 2019 roku stwierdzono zapadalność 0,69/100 000 mieszkańców (21). Według serologicznych badań przesiewowych oraz matematycznej analizy uwarunkowań ekologicznych, KZM przypuszczalnie występuje w całej Polsce $(22,23)$. W porównaniu do północno-wschodniej Polski, w województwach położonych w częściach południowo-zachodniej i południowo-wschodniej notuje się więcej zapaleń mózgu o nieokreślonej etiologii(24). Można więc założyć, że część nieokreślonych neuroinfekcji stanowią niezdiagnozowane KZM. Jest to tym bardziej prawdopodobne, że w bezpośrednim sąsiedztwie południowych regionów Polski, w Czechach i na Słowacji, zapadalność na KZM jest istotnie wyższa (około 6,4/100 000). Ponadto, przyczyn niedoszacowania liczby przypadków KZM można się dopatrywać w niecharakterystycznym przebiegu choroby, ograniczonym dostępie do diagnostyki oraz, niestety, w zaniedbaniu obowiązku zgłaszania przypadków infekcji przez lekarzy(25).

\section{LECZENIE}

Leczenie neuroinfekcji wywołanej wirusem KZM ma charakter objawowy. W przypadkach o lżejszym przebiegu wymagane jest podawanie leków przeciwgorączkowych, przeciwbólowych, przeciwwy- 
sibility to change this status quo. Efavirenz and tipranavir (currently used to treat HIV), dasabuvir (used to treat $\mathrm{HCV}$ ), benzavir-2, and flavonoids derived from the roots of the Baikal skullcap (Scutellaria baicalensis) are the most promising substances that show anti-TBE activities (28-30).

\section{COMPLICATIONS AND LONG-TERM CONSEQUENCES OF TBEV INFECTIONS}

Recovery from TBE occurs within a few days or weeks. The severe course of the acute phase of infection carries the risk of permanent neurological complications, observed in up to $50 \%$ of patients (11). The most common of these are cranial and peripheral nerve paralysis and palsy, damage to the brachial plexus and cerebellum, abnormal EEG, and neuropsychological disorders (7). The latter include depression; characteropathy; chronic fatigue; muscle and joint pain; headache and dizziness; learning and working difficulties; difficulty concentrating, remembering, and learning; sleep disorders; and changes in eating habits. TBE infection also increases the likelihood of developing dementia in later years. These nonspecific and poorly understood symptoms are called post-encephalitic syndrome (PES) (31). PES symptoms significantly reduce the patient's quality of life and sometimes force a change in lifestyle.

The reason for the diversity in the course of TBE infection remains unknown. It has been observed that the course of infection is more severe in adults and that the risk of permanent complications after the illness increases with age (32). Recent studies showed that the clinical variability of the disease is linked to the individual differences in the immune cell accumulation patterns, mainly varying counts of $\mathrm{B}$, Th $\mathrm{CD} 4+$, Tc CD8+ lymphocytes, and different cytokine response $(33,34)$.

Severe complications of TBE in children occur about 10 times less often than in adults. The data on the pediatric population collected so far describe the course and long-term effects of this infection in children only to a limited extent. A Swedish study of 55 children suffering from TBE in 2004-2008 showed that about $75 \%$ experienced chronic headaches, increased fatigue, excessive irritability, difficulty concentrating, and memory problems within 2 to 7 years after the infection (35). Importantly, in a recent Polish study, TBEV was the second most common cause of pediatric CNS infections causing as much as $9 \%$ and $31 \%$ of all meningitis and encephalitis cases, respectively (36). The annual incidence of TBE in children was estimated to 4.08 (95\% CI, 2.07-8.02) per 100,000. Assuming wide-spread distribution of TBE in Poland $(22,23)$, many pediatric TBE cases in Poland remain miotnych, przeciwobrzękowych oraz wyrównywanie zaburzeń elektrolitowych (hiponatremia) i kwasowo -zasadowych (26). Nie istnieją jasno określone zasady leczenia oraz standardy postępowania. Brak konsensusu dotyczącego czasu leczenia i dawek stosowanych leków skutkuje tym, że wszystkie stosowane metody mają charakter autorski. Według doświadczeń własnych stosowanie deksametazonu u dzieci z ciężkim przebiegiem KZM w dawce do $0,6 \mathrm{mg} / \mathrm{kg} /$ dobę (maksymalnie $16 \mathrm{mg} /$ dobę) w 4 dawkach podzielonych przez 2-5 dni ze stopniową redukcją dawki przez 1-2 dni przynosi korzystne efekty terapeutyczne. Opisano również pojedyncze próby leczenia chorych za pomocą analgosedacji, hiperwentylacji, hipotermii, dekompresyjnej hemikraniektomii, a także dożylnych immunoglobulin (27). Pomimo że terapie przeciwwirusowe nie mają obecnie zastosowania w praktyce klinicznej, wiele badań in vitro daje nadzieje na zmianę tego stanu. Najbardziej obiecującymi substancjami, dla których w badaniach in vitro wykazano działanie przeciw wirusowi KZM są efavirenz oraz tipranavir (obecnie stosowane w leczeniu HIV), dasabuvir (używany w leczeniu HCV), benzavir-2 oraz flawonoidy pozyskiwane z korzeni tarczycy bajkalskiej (Scutellaria baicalensis) (28-30).

\section{POWIKŁANIA I ODLEGŁE NASTĘPSTWA ZAKAŻENIA KZM}

Powrót do zdrowia po przechorowaniu KZM następuje w ciągu kilku dni lub tygodni. Ciężki przebieg ostrej fazy zakażenia niesie ryzyko pozostawienia trwałych powikłań neurologicznych, obserwowanych nawet u 50\% pacjentów (11). Najczęstszymi z nich są porażenia oraz niedowłady nerwów czaszkowych i obwodowych, uszkodzenie splotu barkowego, móżdżku, nieprawidłowe EEG, a także zaburzenia neuropsychologiczne (7). Te ostatnie obejmują swoim spektrum depresję, charakteropatię, przewlekłe zmęczenie, bóle mięśni i stawów, bóle i zawroty głowy, trudności w nauce i pracy, trudności z koncentracją uwagi, zapamiętywania oraz uczenia się, zaburzenia snu i zmiany nawyków żywieniowych. Zakażenie wirusem KZM zwiększa także prawdopodobieństwo wystąpienia demencji w późniejszym wieku. Te niespecyficzne i trudne do uchwycenia objawy ujęto pod nazwą tzw. zespołu postencefalicznego (post-encephalitic syndrome, PES) (31). Objawy PES istotnie obniżają jakość życia chorego oraz niekiedy wymuszają zmianę stylu życia.

Przyczyna zróżnicowania przebiegu zakażenia wirusem KZM pozostaje nieznana. Zaobserwowano, że przebieg zakażenia jest cięższy u dorosłych, a ryzyko trwałych powikłań po przechorowaniu KZM wzrasta wraz z wiekiem (32). Zasadniczy wpływ na przebieg 
unrecognized. These disturbing facts clearly indicate the need to continue research into the incidence and long-term effects of TBE in children.

\section{PREVENTION}

An important element of TBE prevention is avoiding tick bites by wearing appropriate clothing and using effective repellents. However, protection against tick bites cannot replace vaccination, which is the most effective method of preventing TBE. Two vaccines containing inactivated virus strains are currently available in Europe. After a full 3-dose vaccination course, $96-99 \%$ of those who are vaccinated develop immunity (37). The Austrian example demonstrates the effectiveness of vaccination in gaining control over TBE. In Austria, thanks to the large information campaigns that have been ongoing since the beginning of the 1980s, the rates of vaccination against TBE in some regions have reached $95 \%$, while the number of cases has decreased from several hundred to about 50-100 per year (38).

Because of the genetic similarities between flaviviruses, the immune response to vaccination or infection with one flavivirus is modulated by immunological memory and the production of antibodies after previous contact with other flaviviruses. This phenomenon is named the original antigenic sin (39). Cross-reactive circulating antibodies that are produced in response to one virus type do not protect against the other types of the virus. Instead, they contribute to antibody-mediated strengthening of the infection, which is particularly important in dengue fever (40). They can also negatively influence the effectiveness of vaccination against TBE (41). An increased production of cross-reactive non-neutralizing IgG antibodies was also observed during infection with Zika virus in individuals previously vaccinated against TBE (42). Due to the rapid spread of flaviviruses, the impact of flavivirus infection on the course of subsequent infections with other species and the effectiveness of vaccination require further research.

\section{SUMMARY}

The potentially severe course of infection and the risk of permanent neurological complications make TBE an important health problem in Europe. Many aspects of this infection are still not fully understood, and prevention is currently the only effective way of fighting it.
KZM ma nie tyle zjadliwość samego wirusa, co prawdopodobnie reakcja układu odpornościowego osoby zakażonej. U osób z ciężkim oraz łagodnym przebiegiem zakażenia wirusem KZM obserwowano różnice w liczbie limfocytów B, Th CD4+, Tc CD8+ oraz w stężeniach cytokin i chemokin $(33,34)$.

Poważne powikłania KZM wśród dzieci są opisywane około 10 razy rzadziej, niż u osób dorosłych. Dotychczas zebrane dane dotyczące populacji pediatrycznej jedynie pobieżnie opisują przebieg, jak i odległe skutki zakażenia u dzieci, a informacje na temat odległych następstw zakażenia u dzieci są ograniczone. Badania przeprowadzone w Szwecji obejmujące 55 dzieci chorujących w latach 2004-2008 na KZM wykazały, że około $75 \%$ z nich doświadczało przewlekłych bólów głowy, wzmożonej męczliwości, nadmiernej drażliwości oraz trudności z koncentracją i funkcjonowaniem pamięci w przeciągu 2 do 7 lat po infekcji (35). Według najnowszego polskiego badania KZM jest drugą najczęstszą przyczyną zakażeń OUN w populacji pediatrycznej w województwie podlaskim. Wirus KZM był odpowiedzialny za aż $9 \%$ przypadków zapaleń opon mózgowo-rdzeniowych i 31\% wszystkich przypadków zapalenia mózgu (36). Roczną zapadalność wśród dzieci poniżej 18 r.ż. oszacowano na 4.08 (95\% CI, 2,07-8,02) przypadków na 100000 dzieci. Jeżeli zgodnie z szacunkami Stefanoff i wsp $(22,23)$ zakażenia KZM są w Polsce znacznie bardziej rozpowszechnione, to duża część zakażeń wśród dzieci pozostaje nierozpoznana. Te niepokojące fakty jednoznacznie wskazują na potrzebę kontynuacji badań nad częstością występowania i odległymi skutkami KZM u dzieci.

\section{PROFILAKTYKA}

Ważnym elementem profilaktyki KZM jest unikanie ataków kleszczy przez zakładanie odpowiedniej odzieży i stosowanie skutecznych repelentów. Ochrona przed kleszczami nie zastąpi jednak szczepień, które są najskuteczniejszą metodą prewencji KZM. W Europie dostępne są obecnie dwie szczepionki zawierającego inaktywowane szczepy wirusa. Po pełnym 3-dawkowym cyklu szczepienia 96-99\% zaszczepionych wytwarza odporność (37). Skuteczności szczepień w uzyskaniu kontroli nad KZM w populacji dowodzi przykład austriacki. W Austrii dzięki szeroko zakrojonej kampanii informacyjnej prowadzonej od początku lat '80-tych, wyszczepialność przeciwko KZM sięga w niektórych regionach $95 \%$, a liczba zachorowań zmniejszyła się z kilkuset do około 50-100 rocznie (38).

Pokrewieństwo genetyczne flawiwirusów sprawia, że reakcja odpornościowa na szczepienie lub zakażenie jednym flawiwirusem jest modulowana przez pamięć 


\section{REFERENCES}

1. Michelitsch A, Wernike K, Klaus C, et al. Exploring the Reservoir Hosts of Tick-Borne Encephalitis Virus. Viruses 2019;11. https://doi. org/10.3390/v11070669.

2. European Centre for Disease Prevention and Control. Tick-borne encephalitis. Stockholm: ECDC. Annual epidemiological report for 2018; 2019.

3. Yoshii K. Epidemiology and pathological mechanisms of tick-borne encephalitis. J Vet Med Sci 2019;81:343-7. https://doi.org/10.1292/jvms.180373.

4. Pukhovskaya NM, Morozova OV, Vysochina NP, et al. Tick-borne encephalitis virus in arthropod vectors in the Far East of Russia. Ticks Tick Borne Dis 2018;9:824-33. https://doi.org/10.1016/j. ttbdis.2018.01.020.

5. Kř́iž B, Fialová A, Šebestová H, et al. Comparison of the epidemiological patterns of Lyme borreliosis and tick-borne encephalitis in the Czech Republic in 2007-2016. Epidemiol Mikrobiol Imunol 2018;67:134-40.

6. Garcia-Vozmediano A, Krawczyk AI, Sprong $\mathrm{H}$, et al. Ticks climb the mountains: ixodid tick infestation and infection by tick-borne pathogens in the Western Alps. Ticks and Tick-Borne Diseases 2020:101489. https://doi.org/10.1016/j. ttbdis.2020.101489.

7. Arnež M, AvšiččŽupanc T. Tick-borne encephalitis in children: an update on epidemiology and diagnosis. Expert Review of Anti-Infective Therapy 2009;7:1251-60. https://doi.org/10.1586/ eri.09.99.

8. Przygodzka M, Mikulak E, Chmielewski T, et al. Repellents as a major element in the context of prevention of tick-borne diseases. Przegl Epidemiol 2019:269-80. https://doi.org/10.32394/pe.73.25.

9. Kunze U. The International Scientific Working Group on Tick-Borne Encephalitis (ISW TBE): Review of 17 years of activity and commitment. Ticks and Tick-Borne Diseases 2016;7:399-404. https://doi.org/10.1016/j.ttbdis.2015.12.018.

10. Król ME, Borawski B, Nowicka-Ciełuszecka A, et al. Outbreak of alimentary tick-borne encephalitis in Podlaskie voivodeship, Poland. Przegl Epidemiol 2019:239-48. https://doi.org/10.32394/pe.73.01.

11. Kaiser R. Tick-borne encephalitis. Infect Dis Clin North Am 2008;22:561-75, x. https://doi. org/10.1016/j.idc.2008.03.013.

12. Bogovic P, Strle F. Tick-borne encephalitis: A review of epidemiology, clinical characteristics, and management. World J Clin Cases 2015;3:430 41. https://doi.org/10.12998/wjcc.v3.i5.430.

13. Saksida A, Duh D, Lotric-Furlan S, et al. The importance of tick-borne encephalitis virus RNA immunologiczną i produkcję przeciwciał po poprzednich kontaktach z innymi flawiwirusami. Zjawisko to nazwano ,pierwotnym grzechem antygenowym” (ang. original antigenic sin) (39). Krążące przeciwciała reaktywne krzyżowo powstałe w odpowiedzi na jeden rodzaj wirusa nie chronia jednak przed zakażeniem innymi typami wirusa. Wprost przeciwnie, przyczyniają się do antygenowego wzmocnienia zakażenia, które jest szczególnie istotne w dendze (40). Mogą także negatywnie wpływać na skuteczność szczepień przeciwko KZM (41). Z kolei u osób uprzednio zaszczepionych przeciwko KZM, zakażenie wirusem Zika powodowało zwiększenie miana nieneutralizujących przeciwciał IgG reagujących krzyżowo (42). Wobec gwałtownego rozprzestrzeniania się flawiwirusów, wpływ zakażenia nimi na przebieg kolejnych zakażeń innymi gatunkami i skuteczność szczepień jest zjawiskiem wymagającym dalszych badań.

\section{PODSUMOWANIE}

Potencjalnie ciężki przebieg zakażenia oraz ryzyko trwałych powikłań neurologicznych powoduja, że zakażenie wirusem KZM stanowi ważny problem zdrowotny w Europie. Wiele aspektów dotyczących zakażenia pozostaje jak dotąd nie w pełni poznanych. Profilaktyka stanowi obecnie jedyny skuteczny sposób walki z zakażeniem.

detection for early differential diagnosis of tickborne encephalitis. J Clin Virol 2005;33:331-5. https://doi.org/10.1016/j.jcv.2004.07.014.

14. Lindquist L. Tick-borne encephalitis. Handbook of Clinical Neurology, vol. 123, Elsevier; 2014, p. 531-59. https://doi.org/10.1016/B978-0-44453488-0.00025-0.

15. Musso D, Desprès P. Serological Diagnosis of Flavivirus-Associated Human Infections. Diagnostics (Basel) 2020;10. https://doi. org/10.3390/diagnostics10050302.

16. Mishra N, Caciula A, Price A, et al. Diagnosis of Zika Virus Infection by Peptide Array and Enzyme-Linked Immunosorbent Assay. MBio 2018;9. https://doi.org/10.1128/mBio.00095-18.

17. de Graaf JA, Reimerink JH, Voorn GP, et al. First human case of tick-borne encephalitis virus infection acquired in the Netherlands, July 2016 [published correction appears in Euro Surveill. 2016 Aug 25;21(34):]. Euro Surveill. 2016;21(33):30318. doi:10.2807/1560-7917.ES.2016.21.33.30318

18. Beauté J, Spiteri G, Warns-Petit E, et al. Tickborne encephalitis in Europe, 2012 to 2016. Euro Surveill 2018;23. https://doi.org/10.2807/15607917.ES.2018.23.45.1800201. 
19. Zeman P. Prolongation of Tick-Borne Encephalitis Cycles in Warmer Climatic Conditions. International Journal of Environmental Research and Public Health 2019;16:4532. https://doi. org/10.3390/ijerph16224532.

20. Steffen R. Tick-borne encephalitis (TBE) in children in Europe: Epidemiology, clinical outcome and comparison of vaccination recommendations. Ticks and Tick-Borne Diseases 2019;10:100-10. https://doi.org/10.1016/j.ttbdis.2018.08.003.

21. Czarkowski MP, Cielebąk E, Kondej B, et al. Infectious diseases and poisonings in Poland in 2019 - preliminary data. Warsaw: National Institute of Public Health - National Institute of Hygiene Department of Epidemiology and Surveillance of Infectious Diseases and Chief Sanitary Inspectorate - Department of Epidemic Prevention and Border Sanitary Protection; 2020.

22. Stefanoff P, Rubikowska B, Bratkowski J, et al. Predictive Model Has Identified Tick-Borne Encephalitis High-Risk Areas in Regions Where No Cases Were Reported Previously, Poland, 19992012. Int J Environ Res Public Health 2018;15. https://doi.org/10.3390/ijerph15040677.

23. Stefanoff P, Siennicka J, Kaba J, et al. Identification of new endemic tick-borne encephalitis foci in Poland - a pilot seroprevalence study in selected regions. International Journal of Medical Microbiology 2008;298:102-7. https:/doi. org/10.1016/j.ijmm.2008.04.002.

24. Czarkowski MP, Cielebąk E, Kondej B, et al. Infectious diseases and poisonings in Poland in 2018. Warsaw: National Institute of Public Health - National Institute of Hygiene Department of Epidemiology and Surveillance of Infectious Diseases and Chief Sanitary Inspectorate Department of Epidemic Prevention and Border Sanitary Protection; 2019.

25. Drelich A, Kruszyński P, Wąsik TJ. Etiopatogeneza kleszczowego zapalenia mózgu (KZM). ANNALES ACADEMIAE MEDICAE SILESIENSIS n.d.:12.

26. Riccardi N, Antonello RM, Luzzati R, et al. Tickborne encephalitis in Europe: a brief update on epidemiology, diagnosis, prevention, and treatment. European Journal of Internal Medicine 2019;62:16. https://doi.org/10.1016/j.ejim.2019.01.004.

27. Taba P, Schmutzhard E, Forsberg P, et al. EAN consensus review on prevention, diagnosis and management of tick-borne encephalitis. Eur J Neurol 2017;24:1214-e61. https://doi.org/10.1111/ ene. 13356.

28. Leonova GN, Shutikova AL, Lubova VA, et al. Inhibitory Activity of Scutellaria baicalensis Flavonoids against Tick-Borne Encephalitis Virus. Bull Exp Biol Med 2020;168:665-8. https://doi. org/10.1007/s10517-020-04776-y.
29. Stefanik M, Valdes JJ, Ezebuo FC, et al. FDAApproved Drugs Efavirenz, Tipranavir, and Dasabuvir Inhibit Replication of Multiple Flaviviruses in Vero Cells. Microorganisms 2020;8:599. microorganisms8040599.

30. Gwon Y-D, Strand M, Lindqvist R, i in. Antiviral Activity of Benzavir-2 against Emerging Flaviviruses. Viruses 2020;12:351. https://doi. org/10.3390/v12030351.

31. Więdłocha M, Marcinowicz P, Stańczykiewicz B. Psychiatric Aspects of Herpes Simplex Encephalitis,Tick-Borne Encephalitis and Herpes Zoster EncephalitisAmong Immunocompetent Patients. Adv Clin Exp Med 2015;24:361-71. https://doi.org/10.17219/acem/40460.

32. Haglund M, Günther G. Tick-borne encephalitispathogenesis, clinical course and long-term followup. Vaccine 2003;21:S11-8. https://doi.org/10.1016/ S0264-410X(02)00811-3.

33. Toczylowski K, Grygorczuk S, Osada J, et al. Evaluation of cerebrospinal fluid CXCL13 concentrations and lymphocyte subsets in tickborne encephalitis. Int J Infect Dis 2020. https:// doi.org/10.1016/j.ijid.2020.01.023.

34. Grygorczuk S, Osada J, Toczyłowski K, et al. The lymphocyte populations and their migration into the central nervous system in tick-borne encephalitis. Ticks and Tick-Borne Diseases 2020;11:101467. https://doi.org/10.1016/j.ttbdis.2020.101467.

35. Fowler A, Forsman L, Eriksson M, et al. TickBorne Encephalitis Carries a High Risk of Incomplete Recovery in Children. vol. 163. 2013. https://doi.org/10.1016/j.jpeds.2013.01.037.

36. Toczylowski K, Bojkiewicz E, Barszcz M, et al. Etiology, Clinical Presentation and Incidence of Infectious Meningitis and Encephalitis in Polish Children. Journal of Clinical Medicine 2020;9:2324. https://doi.org/10.3390/jcm9082324.

37. Schosser R, Reichert A, Mansmann U, et al. Irregular tick-borne encephalitis vaccination schedules: the effect of a single catch-up vaccination with FSME-IMMUN. A prospective non-interventional study. Vaccine 2014;32:237581. https://doi.org/10.1016/j.vaccine.2014.01.072.

38. Kunze U, Böhm G. [Tick-borne encephalitis (TBE) and TBE-vaccination in Austria: Update 2014]. Wien Med Wochenschr 2015;165:290-5. https:// doi.org/10.1007/s10354-015-0362-9.

39. Monto AS, Malosh RE, Petrie JG, et al. The Doctrine of Original Antigenic Sin: Separating Good From Evil. J Infect Dis 2017;215:1782-8. https://doi.org/10.1093/infdis/jix173.

40. Slon Campos JL, Mongkolsapaya J, Screaton GR. The immune response against flaviviruses. Nat Immunol 2018;19:1189-98. https://doi.org/10.1038/ s41590-018-0210-3. 
41. Bradt V, Malafa S, von Braun A, i in. Pre-existing yellow fever immunity impairs and modulates the antibody response to tick-borne encephalitis vaccination. NPJ Vaccines 2019;4:38. https://doi. org/10.1038/s41541-019-0133-5.

42. Malafa S, Medits I, Aberle JH, i in. Impact of flavivirus vaccine-induced immunity on primary Zika virus antibody response in humans. PLoS Neg1 Trop Dis 2020;14:e0008034. https://doi. org/10.1371/journal.pntd.0008034.
Received: 14.08 .2020

Accepted for publication: 11.10 .2020

Otrzymano: 14.08.2020 r.

Zaakceptowano do publikacji: $11.10 .2020 \mathrm{r}$.

Address for correspondence:

Adres do korespondencji:

Assoc. prof. Artur Sulik, MD, PhD,

Medical University of Bialystok,

Department of Pediatric Infectious Diseases, ul. Waszyngtona 17, 15-274 Bialystok e-mail: artur.sulik@umb.edu.pl 